\title{
ReSEARChArTicle \\ Evaluation of promising pre-release inter specific cotton hybrids
}

\author{
Harphool Meena, K.C. Nagar and B.L. Kumhar
}

\section{SUMMARY}

Field experiment was conducted at Agricultural Research Station, Borwat Farm, Banswara during Kharif-2012 to find out the optimum plant geometry and fertility levels for inter specific cotton hybrids. Sowing of RAHB-189 cotton hybrid gave significantly higher seed cotton yield $\left(1798 \mathrm{~kg} \mathrm{ha}^{-1}\right)$ over DCH-32. The maximum seed cotton yield $\left(1976 \mathrm{~kg} \mathrm{ha}^{-1}\right)$ was observed under plant geometry of $90 \times 60 \mathrm{~cm}$ than closer plant geometry of $90 \times 45 \mathrm{~cm}$ and wider plant spacing $90 \times 90 \mathrm{~cm}$. Though, yield attributing parameters such as bolls plant ${ }^{-1}$ and boll weight were statically improved in wider as compared to closer spacing it could be increase the seed cotton yield under sowing at $90 \times 60 \mathrm{~cm}$ plant spacing. Among fertility levels, similar seed cotton yield was recorded with the application of $100 \%$ RDF $\left(1983 \mathrm{~kg} \mathrm{ha}^{-1}\right)$ and $125 \% \mathrm{RDF}(2018 \mathrm{~kg}$ $\mathrm{ha}^{-1}$ ) but both were significantly better than that of $75 \% \mathrm{RDF}$ and plant geometry 90 x $60 \mathrm{~cm}$ seemed to be ideal for inter specific hybrid cotton for realizing higher productivity under the specific agro climatic zone IV $b$.

Key Words : Inter specific cotton, Plant geometry, Seed cotton yield, Fertility levels

How to cite this article: Meena, Harphool, Nagar, K.C. and Kumhar, B.L. (2018). Evaluation of promising pre-release inter specific cotton hybrids. Internat. J. Plant Sci., 13 (1): 192-195, DOI: 10.15740/HAS/IJPS/13.1/192-195.

Article chronicle : Received : 03.11.2017; Revised : 12.12.2017; Accepted : 26.12.2017

\section{$\longrightarrow$ MEMBERS OF THE RESEARCH FORUM}

Author to be contacted :

Harphool Meena, Agricultural Research Station (A.U.), Ummedgang

Farm, Kota (Rajasthan) India

Email : hpagron@rediffmail.com

Address of the Co-authors:

K.C. Nagar, Krishi Vigyan Kendra, Bhilwara (Rajasthan) India

B.L. Kumhar, Jawaharlal Nehru Krishi Vishwavidyalaya, Jabalpur (M.P.) India 